\title{
Lexical imitation and lexical creation in contemporary Romanian
}

\author{
Ana Ene \\ Faculty of Letters, Transilvania University of Brașov, Bd. Eroilor 29, 500036 Brașov, Romania
}

\section{Article info}

History:

Received August 4, 2019

Accepted September 1, 2019

Published November 7, 2019

Key words:

semantics

sociolinguistics

stylistics

\begin{abstract}
The present paper analyses lexical imitation and creation in contemporary Romanian, as two important processes of developing the individual and collective lexis, along with the various forms of borrowing and the internal lexicalgrammatical techniques of vocabulary enrichment.

Setting the perimeter of the investigation entails: 1) clarifying the two concepts and, due to the complexity of the phenomena and the diversity of occurrences both in the specialised language, in the non-specialized language, as well as in the colloquial and argotic language, a typological approach will follow. The subsequent objective 2) consists in the identification and description of the lexical-semantic mechanisms involved in lexical imitation and creation. Furthermore, as lexical imitation and lexical creation are substantial sources of expressiveness, my endeavour also involves 3) studying their special role in the dynamics of the slang, depending on the degree of communicational complicity determined by such special lexical items.

The accomplishment of these objectives requires a chiefly linguistic methodology and the instruments used pertain mainly to the semantic and lexicalparadigmatic patterns of analysis. Given the necessity of considering the context, the discursive parameters and the quantification of the expressiveness of the argotic terms, the present investigation will require instruments of pragmastylistics and sociolinguistics analysis.
\end{abstract}

\section{Introduction. The clarification of the concepts}

The special status of Romanian as the only representative language of Latinity in Eastern Europe has secured, in time, an important place for itself in the specialized literature. The uniqueness of Romanian as an Oriental Romance language is but one aspect of the interest it has stirred. Its poignant individuality is also proven by its openness to borrowings and by its impressive creative force. The phrase 'hospitable language, coined by the well-known Swedish linguist Alf Lombard (1969, p. 646) has become well-established, being present in most of the theoretical studies dedicated to Romanian.

Lexical imitation and lexical creation are defined as manners of enriching the individual and collective lexis. The first of these lexical phenomena, lexical imitation, is the acquisition of some words or expressions encountered by speakers in various circumstances, as a result of either the impact that the respective lexical items had upon them or of the acknowledged need for their inclusion in the speakers' personal word-stock. Thus, at first glance, the trigger of this process is primarily psychological. If the acquisition is adequately performed, intelligent imitation brings about the reproduction of the respective words in other combinations than the ones encountered or even the fairly prompt creation of lexical families departing from the base acquired through imitation. Inadequate acquisition leads to defective imitation with particularly hilarious outcomes (especially when the speaker is imbued with the "elevated" character of their speech): Caragiale ${ }^{a}$ is an expert at artistically exploiting language errors to various ends - the anthological

\footnotetext{
^Email address:enea@unitbv.ro.

${ }^{a}$ Ion Luca Caragiale, famous Romanian playwright (1852-1912).
} 
expression "legea de murături" (the law of pickles [sic!]) is used by Master Leonida ${ }^{1}$ to wisely explain to his spouse Efimița that the law in question (the correct term being [lege de] moratoriu ${ }^{2}$ (moratorium) - "a law that provisions the delay of the payment of debts") would mean that "none shall have the right to pay their debts". Or, by the same token, here is the manner in which a lady expressed herself when telling a friend why she had to cut short her vacation: "Dragă, deci fortuită de boala copilului, am fost obligată să mă întorc mai repede acasă" ("My dear, being fortuitous by the child's illness, I was obligated to return home sooner") - a double mistake as fortuitous ("accidental") is used by the speaker with the meaning "forced, obligated" and it is repeated in the verb structure. These defective acquisitions-triggered by carelessness or by the minimal context in which the word had been acquired, by poor education or by cultural poverty-generate language mistakes (folk etymologies, semantic accidents, semantic incongruences, phonetic accidents, etc.).

The second lexical phenomenon, lexical creation (or lexical innovation), does not entail a model per se any more ${ }^{\mathrm{b}}$ : "Everything that, in a speaker's utterance, diverges-linguistically-from the existing language in which the verbal exchange is carried out can be called innovation" (Coșeriu, 1997, p. 70).

Lexical creation is grounded on a transfer which is also psychologically motivated. The transfer is achieved in two ways: transfer with material expression and transfer without material expression.

The transfer with material expression consists in attaching a suffix or a prefix to a stem or root to which it had never been associated before: e.g. the neological suffix -bil (Fr. -ble, Engl. -ble) initially used mainly in scientific language, extended to the administrative and literary languages but was still used for borrowed words. Then, complying with the basic structure (infinitive + the suffix $-b i l$ ), it ended up being attached to native word stems thus generating analogical structures: apărabil (defendable), auzibil (audible), locuibil (inhabitable), etc. (Coteanu et al., 1985, p. 164). As in the case of certain lexical imitations, the creations based on this type of transfer tend to develop lexical families or they can later replicate in various combinations (sustained by calque or not, therefore a combination between creation and imitation): albicios, alburiu, albişor, albior etc. (whitish); rasă albă (white race), a semna în alb (to sign in blank), albul ochiului (the white of the eye), a fi alb ca varul (to be as white as a sheet), cu părul alb (white-haired), etc.

The transfer without material expression solely alters the semantic content therefore it is a more or less complex resemantisation: a word is given a meaning that it has never had before and, furthermore, it is not directly related to the signified object. Most of these resemantisations are in fact metaphors, but that type more or less cryptic, which rather proposes similarities between elements brought together than highlights some already existing in reality. The so-called 'classic' type of metaphor has already been very clearly defined by Tudor Vianu:

A metaphor involves the alternation in consciousness of two series of representations: 1) a series of the similarities between the reality designated by the word itself and the reality designated by it in metaphorical form; 2) a series of differences between the two realities. The metaphor is psychologically supported by the perception of a unity of things through the veil of differences between them.

(Vianu, 1968, p. 307)

Hence, these types of transfer are more or less surprising: apart from their core meaning, the words receive (in colloquial language) an additional meaning that has (almost) nothing to do with the denotative sense. For example, a woman who is considered "stupid, dumb, simple, frivolous" is called gîscăa (goose) and the word bou (ox) now labels male stupidity in Romanian. Moreover, we often come across utterances such

\footnotetext{
${ }^{1}$ The main character in the comedy Conu Leonida față cu reacțiunea [Master Leonida face to face with the Reaction - my translation] published in 1880 .

${ }^{2}$ The lexical-semantic error is evidently generated by the homophony between the two terms murături [pickles] and moratoriu [moratorium].

${ }^{b}$ All the following quotations from the works of Romanian authors are my translations.
} 
as: Ești un porc! (You are a pig! - to designate an unscrupulous / ignoble / lewd, etc. individual), X se dă leu (X poses as a lion - for a person who feigns courage / authority, etc.). The metaphorical mechanism involved by these last examples is somewhat clearer: it is based either on an obvious characteristic of the comparative term (courage, for X poses as lion) or on a cultural characteristic (filth, for You are a pig!). The colloquial-argotic language furnishes countless similar creations based on semantic transfer, apparently without any connection to the denotative sense of the lexemes in question: pește (fish) for "procurer", curcan (turkey) or sticlete (goldfinch) for "policeman", termometru (thermometer) for "policemen's rubber baton", etc. Obviously, in all cases there could be a certain motivation (the goose and the ox are not among the most intelligent animals, the pig is not among the cleanest of animals, the lion is considered "the king of beasts"; the fish is slippery, the turkey has a puffed-out aspect and the goldfinch draws attention on account of its being lively coloured; the thermometer looks like a baton). Therefore, either this motivation is not scientifically grounded, or it is a secondary characteristic which is more or less dependent upon the environment and the cultural prototype. But, whatever the motivation, this invariably results from a connotative leap within the respective lexical creations.

Certainly, most languages possess such lexical creations resulting from transfers without material expression. Some of them are often analysed in connection to depreciation, one of the two optional directions of meaning change:

Two other traditional categories in the analysis of meaning change are pejorization (Latin pejor 'worse') and ameliorization (Latin melior 'better'). These refer to change in word-evaluative force. In pejorization, a word takes on a derogatory meaning. This is frequently seen with words for animals, which can be used tot refer to people negatively or insultigly, as when someone is called a monkey, parasite, pig, sow, and so on.

(Riemer, 2010, p. 374-375)

In poetic language, such creations (which can also be transfers with material expression) are dominant, they are obtained in various ways and they can be based on mechanisms and associations which are sometimes difficult to detect. Other times, the transfer with material expression can be simulated: a lexical / grammatical suffix can be attached to a previously non-existent base. Here is, for example, the term trimbulinzi) (used both as an adjective and as a noun and having also plural: trimbulinzi), lexical creation of the Romanian poet Nichita Stănescu ${ }^{3}$. The suffix attached here to an invented lexical basis is a grammatical one, a gerundive suffix, which means the resulting word is morphologically converted to an adjective or a noun.

Obviously, in the case of lexical creation, there can be intelligent lexical creation or just "momentary creations" $(1,4,5)$, generally justified by a markedly ironic stylistic context/register (Guțu-Romalo, 2000, p. 175) and there can also be unsuccessful creations $(2,3)^{c}$ :

(1) amicalitate: „Starea de amicalitate produce numai propoziții în care evlavia se îmbină cu adorația” ("The state of amicality [sic!] triggers only statements in which belief merges with adoration"), in "Săptămîna" 1971, no. 10, p. 7/1 (Guțu-Romalo, 2000, p. 175-176); the word was formed by attaching the suffix -itate to the word amical; the derived word doubles the abstract noun amiciție (amicability), which is well-established in Romanian;

(2) pierzant: „Marele pierzant... este, însă, guvernul de centru-dreapta” (“The greatest loser [...] is, however, the center-right government"), in "Lumea”, 1980, no. 50, p. 6, column 2 (Avram, 1987, p. 247); a lexical creation based on a pierde (to lose) to which the suffix -ant was added, preferred to the

\footnotetext{
${ }^{3}$ The term appears in several poems: for example, in the poem Cîntec în doi [Song by two] ("Noi nu vrem să fim geniali / Noi vrem să fim trimbulinzi"; Eng. "We do not want to be brilliant / We want to be trimbulinzi" - my translation) in the volume Necuvintele [The Nonwords] published in 1969. To sum up, the term was interpreted as "nonconformist", "eager for knowledge, open to new experiences".

${ }^{\mathrm{c}}$ All following examples are translated in English by myself.
} 
neologism perdant (of French origin) because, probably, it was evocative of the noun pierzanie (loss, doom) which was considered more appropriate in the context and within the respective statement;

(3) vizuiență: „uriașa audiență sau vizuiență a filmului” ("the huge audience or viewence [sic!] of the film"), in "Luceafărul", 1980, no. 17 (943), p. 4, column 3 (Avram, 1987, p. 247); in this case the forced analogy with audiență (audience) as if it were formed by adding the suffix - ență, although it is a neologism (originating from the French word audience); however, the Romanian noun audience (having the initial meaning of "meeting granted to an applicant by a person in a high position") has recently added the meaning of audience from English by semantic calque;

(4) cîrtițărit: „industria cîrtițăritului” ("the ground-hogging industry”), in “Scînteia”, 1982, no. 12405, p. 6, column 6 (Avram, 1987, p. 241); the word refers to the "industry" of underground shelters and it is easily decoded in context-cîrtiţă (mole) + the suffix - (ăr)it-if the colloquial language is naturally used (which is valid for native speakers);

(5) profitozaur: Profitozaurii (Profitosaurs) - article title, in “Informația Bucureștiului", 1983, no. 9224, p. 4, columns 1-3 (Avram, 1987, p. 241); it is a "portmanteau word” lexical creation in which the lexemes profitor (profiteer) and dinozaur (dinosaur) are identifiable (in which suppression is followed by adjoining) and it refers to billionaires who earn the highest profits.

The press uses and sometimes even abuses ad-hoc puns, occasional creations such as the ones rendered above.

Unlike lexical imitations, the permanent integration of lexical creations into the language (and, consequently, their inclusion in dictionaries) is much more probable given their almost invariable expressiveness, the contexts in which they are placed are descriptive-connotative (generally involving occasional connotations regarded as mere possibilities and not connotations which are deeply rooted into the language and which characterize the lexeme in its entirety, as in the case of polysemy, for example).

\section{Lexical imitation and lexical creation - a typological endeavour}

Our objective in the following is not that of offering extensive lists of examples. The latter have already been put forward, they have been analysed from various perspectives and accompanied by subtle commentary in influential studies by leading authors such as: Dimitrescu (1994, 1997), Hristea (1984), Bidu-Vrănceanu (1997), Avram (1997), Guțu-Romalo (2000, 2005), Zafiu (2001, 2010), Gruiță (2006), Stoichițoiu-Ichim (2007).

Our aim is to provide a typological framework as these phenomena have already been described, exemplified from the perspective of the dynamics of the Romanian lexicon, along with others, in the above-mentioned studies.

\subsection{Lexical imitation}

In the following, I will present the lexical imitation as it appears in the contemporary Romanian language, but also the way it is described in the recent literature.

\subsubsection{Imitația lexicală rezultată din imprumuturile propriu-zise}

The forms of lexical imitation generated by actual borrowings are very well represented in contemporary Romanian: binom (binomial) < Fr. binôme, paralelipiped (parallelepiped) < Fr. parallélipipède, congruență (congruence) $<$ Fr. congruence, atom (atom) < Fr. atom, nucleu (nucleus) < Fr. nucléus, eprubetă (test tube) $<$ Fr. éprouvette, clorofilă (clorophyll) < Fr. chlorophylle, ferigă (fern) < Lat. filix, -icis, fortuit (fortuitous) $<$ Fr. fortuit, salutar (healthy) < Fr. salutaire, summum (summa) < Lat. summum, vindicativ (vindictive) $<$ Fr. vindicatif, a implementa (to implement) < Eng. to implement, a derula (to unfold) < Fr. dérouler, vizavi (vis-à-vis) < Fr. vis-à-vis, etc.

Regarding the permanent integration of these forms into the language, according to an author who has studied this phenomenon: 
The beneficial or harmful role of learning through imitation depends on the quality of the reference; the influence that they exercise upon the language used at a given time by instituting certain manners of expression depends on the frequency of the reference within social communication and/or on the authority of its most representative users.

(Guțu-Romalo, 2005, p. 249).

\subsubsection{Lexical imitation generated by calque}

Within the typology of calques, the linguistic criterion is the most significant one: "Because it indicates the exact linguistic area in which an imitation occurs, hence the linguistic criterion can be considered the most important in the classification of calque" (Stanciu-Istrate, 2006, p. 309).

The structural criteria, namely the one on which the translation of the elements that form the model relies (according to which there are partial or integral calques) as well as the one regarding the degree of fidelity of the copy in relation to its model (according to which there are approximate, imperfect and perfect calques) are considered sub-criteria, hence subordinate to the linguistic criterion.

Certainly, these are "[...] secondary criteria as they do not engender new types of calque but they illustrate the functioning of the ones which have already been identified according to the linguistic criterion". Moreover, "a morphemic structure calque can be perfect and partial at the same time (e.g. prevedea [Eng. to predict]), perfect and total (e.g. simțămînt [Eng. feeling]), imperfect and total (e.g. anotimp [Eng. season]), approximate and total (e.g. a însărcina [Eng. to commission])" (Stanciu-Istrate, 2006, p. 309310).

In the classification of calques, the following sub-criteria have to be taken into consideration: the sociocultural criterion (common and scientific calque) and the one regarding the origin of the model (unique model calque, multiple and international calques).

Thus, seven fundamental types of calque can be singled out:

- lexical calque: a) morphemic structure calque - abstrage < Fr. abstraire, demers < Fr. démarche; b) semantic structure calque - aer ("mien, countenance, demeanour") < Fr. air, pătură ("social category") < Fr. couche;

- grammatical calque: de conivență cu ("in collusion with", "in agreement with") < Fr. de connivence avec;

- phraseological calque: arte frumoase ("fine arts") < It. belle arti, cf. also Fr. beaux-arts;

- lexical-phraseological calque: caz de conștiință ("case of conscience”) < Fr. cas de conscience; curtea de apel ("the appeal court") < Fr. la cour d'appel;

- lexical-grammatical calque: ținută "demeanour, posture" < Fr. tenue;

- phraseological-grammatical calque: ape subterane ("underground waters") < Fr. eaux souterraines;

- lexical-phraseological-grammatical calque: însărcinat cu afaceri ("in charge of bussines") < Fr. chargé d'affaires; limbă de lemn ("wooden tongue") < Fr. langage de bois.

The semantic structure lexical calque, also termed semantic borrowing in the literature, pertains to the larger phenomenon of polysemy although the new meanings are not always listed in dictionaries. Some of them tend to become ingrained in language, others are perceived as barbarisms, as far-fetched or even useless neological doublets. They enter the language especially via mass-media: "Romanian is, to an unsettling extent, incorrectly and negligently spoken on the radio and on TV" (Guțu-Romalo, 2005, p. 250), but social media (Facebook, chat, etc.) undoubtedly 'contribute' to this phenomenon. The fine-tuning of the linguistic system, primarily determined by the cultural component, will decide upon the adoption or rejection of these new meanings in time: "[...] if the assumption that the speaker creates the language is true, then equally true is the fact that society is the one that perfects it. It chooses or rejects the modifications brought about in language depending on whether or not they fit into the system created by the community" (Capidan, 1943, p. 8-9). 
Other semantic borrowings in the non-specialized language have been added lately to the forms that have already been mentioned in the current specialized literature (for example in Stoichițoiu-Ichim, 2007, p. 58-63). Here are some of the most commonly used in various communication situations and registers:

(6) ataşament: from the English term attachment, in e-mails (or about), "la mesaj sînt două ataşamente" ("there are two attachments to this message"), instead of document anexat (annexed file), a meaning that generates homonymy with the already existing Romanian form ataşament ( $<$ Fr. attachement) meaning "powerful and durable affection for someone/something";

(7) determinat: from the English term determined, especially in the discourse of football players / sports commentators "Echipa a avut un joc determinat" ("The team had a determined game"), instead of decis, precis, coerent (determined, precise, coherent); a useless and confusing doublet as the meaning of determinat in Romanian (< Fr. déterminé) is "definite, straightforward, established";

(8) (a se) focusa (pe): from the English phrasal verb to focus on, in "a se focusa pe absorbția de fonduri europene" ("to focus on EU funds"), instead of a se concentra pe (< Fr. concentrer); in this case we are dealing with a lexical-grammatical calque because the verb does not exist as such in Romanian as only focusare exists (< Germ. fokussieren) but it is used in a technical sense ("concentrarea într-un focar a razelor de unde sau de particule în mișcare" - "the focalisation of rays of waves or moving particles) as a synonym of focalizare (the Romanian noun);

(9) graduare: from the English term graduation, in "ceremonie de graduare" ("graduation ceremony") instead of absolvire (< Lat. absolvere); a useless and confusing doublet similar to the paronymy to gradare "to gradually increase/decrease; to place at intervals" < a grada (Fr. graduer) to which the suffix $-r e$ is added;

(10) nutrient: from the English term nutrient, in "lapte bogat în nutrienți" ("milk which is rich in nutrients"), instead of “[substanțe] nutritive, hrănitoare" ("nutritious, nourishing substances"); it is rather an actual borrowing because in Romanian there are only the adjective nutritiv ( $<$ Fr. nutritif) and the noun nutriment (< Fr. nutriment);

(11) patetic: from the English word pathetic, in "a eșua patetic" ("to fail pathetically") instead of lamentabil, jalnic (lamentably, miserably); a doublet which is perceived as useless and in contradiction with the meaning in Romanian (< Fr. pathétique) "filled with pathos";

(12) audiență: from the English term audience, in a sentence such as "Audiența a aplaudat minute în șir" ("The audience applauded for minutes on end"), instead of public, asistență (< Lat. publicus, < Fr. public; < Fr. assistance); an ineffective and disconcerting doublet because the noun audiență $(<\mathrm{Fr}$. audience) in Romanian means "a hearing granted to someone by a person in a position of power" or "to raise someone's interest/to have an influence on someone" when it is used in the expression a avea audiență la (to have audience with);

(13) expertiză: from the English term expertise, in examples such as "persoană cu expertiză în domeniu" ("a person with expertise in the field"), "Expertiza lui în domeniu este impresionantă" ("His expertise in the field is impressive"), used with the meaning experiență, competență deosebită (experience, special skills); in Romanian expertiză (< Fr. expertise) means "research conducted by an expert regarding a situation, a problem, etc.; an expert report";

(14) vocal: from the meaning "sonorous" of the English adjective vocal, in phrases such as "politician vocal" ("vocal politician"), instead of zgomotos, activ (loud, active), someone who wants to stand out; in Romanian, the meaning of vocal (< Fr. vocal) is "referring to voice; performed with one's voice"hence, the term already existing in Romanian has the basic meaning, that of the actual use of the voice.

All the above forms generate trigger homonymy rather than polysemy if we consider that the new meaning is calqued from a different etymon than the one of the already existing meaning(s) in Romanian. 


\subsection{Lexical creation}

The openness of the Romanian language towards borrowing (as such or in the form of calque) legitimates Alf Lombard's phrase 'hospitable language' (1969, p. 646). This hospitality, an illustration of the evolution of the lexis „in the direction of modernization and internationalization” (Stoichițoiu-Ichim, 2007, p. 7), turns Romanian into a more or less comprehensible language to foreigners in various domains of communication (technology, science, informatics, economics, media, advertising, sports, art, show business, etc.). The powerful influence of Romance languages, exercised from the very first stage of modernization of the Romanian lexis as well as, on the one hand, the recent Latin borrowings imposed by the re-Latinisation trend and, on the other hand, the equally powerful Anglo-American influence, render literary Romanian unintelligible for foreign speakers of Romance languages, for speakers who know one or several such languages and/or Latin, but also for native and non-native speakers of English. The multitude of words from modern Romanian which can be placed in the category of international terms (of Greek-Latin origin), hence common to a significant number of languages, contribute to this comprehensibility.

The remarkable lexical inventiveness of Romanian is complementary to this hospitability, thus its identity as well as the preservation of its other specific elements are secured. Theodor Capidan (1943, p. 1-2) stated that "There is always reciprocity between culture and language: language supports culture and culture supports language. During the existence of a language there are usually two distinguishable stages of development: an accumulation stage and a stage of processing the linguistic material with the help of culture".

If beyond the organicist stance of this assertion we perceive the two stages as being recursive (or even concomitant at times) in the dynamics of languages, then the phenomenon of imitation is more characteristic of the accumulation stages of a language, whereas lexical creation can be associated with the stages of language processing through culture.

Transferul can be undoubtedly considered a legitimate classification criterion for lexical creations as the procedures whereby such creations are accomplished only generate subcategories of the two main ones. These subcategories have already been described and excellently annotated by Stoichițoiu-Ichim (2007, p. 7-15) but examined from the perspective of the recent dynamics of the Romanian language namely the internal procedures of vocabulary enrichment. Therefore, in the classification rendered below, the stylistic register has been chosen as a sub-criterion. Hence, two major categories resulted, each with its own subcategories: lexical creations from transfer with material expression and lexical creations from transfer without material expression.

\subsubsection{Lexical creations resulting from transfer with material expression}

Most of the examples below were taken from the work of the author cited above, to which I have added the forms bunsimţisme, big-mama, Berceni Style, departe, încălzitoare, mîrîtor, Întunericitul.

Thus, here are the two types belonging to lexical creations obtained by transference with material expression:

a) 'necessary' lexical creations ${ }^{4}:$ i) by derivation - antologabil < a antologa (to anthologize) + the suffix - bil, cartelizare < a carteliza (to include into a cartel) + the suffix -re, superaccesorizat < super (super) + accesorizat (accessorised), accept (acceptance-by backformation from the form acceptare), antologa (to anthologize-by backformation from the form antologie), etc.; ii) by compounding actor-vedetă (actor-star), oraş-stațiune (resort-city), microinterviu (micro interview), teledivertisment

\footnotetext{
${ }^{4}$ By extension from the "necessary" / "luxury" derivatives distinction put forward by Sextil Pușcariu, in Limba română, I. Privire generală, 1976 (apud Stoichițoiu-Ichim, 2007, p. 8).
} 
(tele-enterteinment), Oltchim ${ }^{\mathrm{d}}<O l t^{\mathrm{e}}+-$ chim- $^{\mathrm{f}}, \mathrm{CEDO}^{\mathrm{g}}$; iii) by reduction/clipping - afro, homo; iv) by conversion - audiovizual (audiovisual), anticonceptional (contraceptive) - used as nouns;

b) 'luxury' lexical creations ${ }^{5}$ : i) by derivation - aplaudac < a aplauda (to applaud) + the suffix -ac, răspîndac < a răspindi (to spread) + the suffix - ac, spionită < spion (spy) + the suffix -ită, cuponiadă $<$ cupon (coupon) + the suffix -(i)adă, fesenizare (by $\left.F S N^{6}+-i z a+-r e\right)$, becalizare $($ Becali $+-i z a+$ -re), bunsimțisme $e^{8}$ (from composed noun bun-simț [common sense] + -ism); ii) by compounding big-mama ${ }^{9}$, Berceni Style ${ }^{10}$; iii) by reduction/clipping - secu < securist (security officer), prof < profesor (professor), bac < bacalaureat (baccalaureate); iv) by conversion - departe ${ }^{11}$ (far away), incălzitoare ${ }^{12}$ (heating), mîrîtor ${ }^{13}$ (growler), Intunericitul ${ }^{14}$ (The dark man).

In the subcategory of 'luxury' creations by conversion we also have to include the following situation, which exists in other languages as well, regarding parts of speech that change their morphological status by (lexical or grammatical) suffixation. Riemer (2010, p. 302) also indicated such cases: Don't baby me; just Google it or Don't "madame" me, young man! I don't like it... The author also stated that these possibilities are not limited to nouns and verbs ${ }^{15}$. Similar structures can also be encountered in the Romanian colloquial language in such utterances as: Nu mă mai „dumnevostri” / „domni” atîta! (Don't 'Sir' me so much).

\subsubsection{Lexical creations resulting from transfer without material expression}

These lexical creations are the result of semantic modification performed in various degrees within the sememe by widening or narrowing of meaning, with or without pejorization/ameliorization of meaning, involving the contribution of a trope to a greater or lesser extent.

The modification by widening/narrowing of meaning occurs without the involvement of any meaning of the etymon, for denominative reasons, this being the so-called denominative neology ${ }^{16}$. When tropes are involved it becomes stylistic neology.

There is also a category of lexical creations, namely the mot-valise lexical creations (portmanteau words), that entails a profound resemantization with a higher degree of expressiveness. Mot-valise do not pertain to stylistic neology because they stem from two or more bases out of which one is predominant from the point of meaning.

All the types ${ }^{17}$ have been thoroughly described and exemplified from other perspectives by Stoichi-

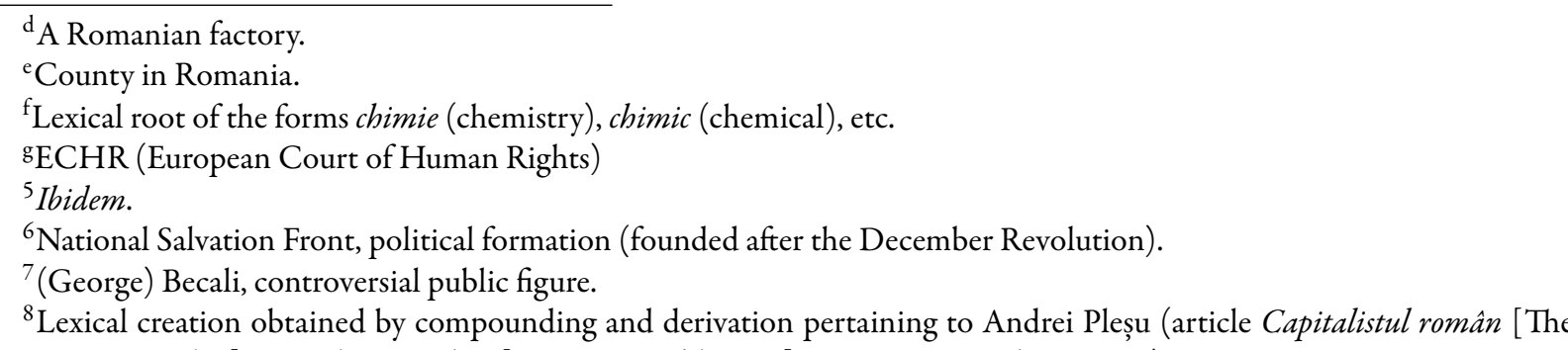
Romanian capitalist], in "Dilema Veche" [The ancient dilemma], no. 201, December / 2007).

${ }^{9}$ In argotic-colloquial language with the meaning of "fat woman", [online].

${ }^{10}$ Name given to a group of supporters of the Rapid football team from Berceni neighbourhood in Bucharest, [online].

${ }^{11}$ In argotic-colloquial language, as an invariable adjective (out of an adverb), with the meaning of "on drugs", [online].

${ }^{12}$ In argotic language, as a noun (out of an adjective), with the meaning of „mistress”, in George Volceanov, Dicționar de argou al limbii române (2007).

${ }^{13}$ In argotic language, as a noun (out of an adjective), with the meaning of „snitch /(former) criminal”, [online].

${ }^{14}$ Noun formed out of the participle intunericit of the folk verb a se intunerici 'to darken' + the suffix -it with a definite article; the pseudonym of the columnist who authors Bula demnitarului ("Dignitary's bulla") in the satirical publication "Academia Cațavencu".

${ }^{15}$ See also: "These possibilities are not limited to nouns and verbs" (Riemer, 2010, p. 302).

${ }^{16}$ Louis Guilbert, La créativité lexicale, 1975 (apud Stoichițoiu-Ichim, 2007, p. 55).

${ }^{17}$ In my view, all the instances of semantic calque signalled by the cited author (Stoichițoiu-Ichim, 2007, p. 58-63) are imitations by calque given the fact that in these cases a type of polysemy, which is facilitated by the same etymon that has generated other meanings in Romanian, is developed. 
țoiu-Ichim (2007, p. 13-14, 55-79). In the classification below some of these examples will be used but they will also be accompanied by my own examples for the existing categories.

Finally, allusive phrases/structures are also lexical creations which are sometimes permeated with intertextuality and evoke, more or less discreetly, various issues, situations, public figures, literary characters, etc. They are obviously more frequent in literature or in the satirical (whether declared or not) press. These will be termed evocative lexical creations (the examples are taken from "Academia Cațavencu"18, henceforth AC).

Thus, the following types of lexical creations from transfer without material expression can be distinguished:

a) lexical creationsby denominative neology: actor (politic) [(political) player], algoritm (politic) [(political) algorithm]; asanare (morală) [(moral) drainage], paliere (ale puterii) [levels (of power)], segment (de public) [(audience) segment], (investitor) strategic [strategic (investor)], inginerie (financiară) [(financial) engineering], etc.;

b) lexical creations by stylistic neology: seism (social) [(social) seism], mamut (industrial) [(industrial) mammoth], dinozaur (politic) [(political) dinosaur], barometru (politic) [(political) barometer], bumerang (electoral) [(electoral) boomerang], firmă-căpuşa ${ }^{19}$, cancerul (corupției) [the cancer (of corruption)], mineriadă (financiară) [(financial) mineriad], burtă (textuală) [(textual) belly], capră (de femeie) [goat (of a woman)], etc.;

c) mot-valise (portmanteau word) lexical creations: ofițăran (ofițer + țăran [officer + peasant]) or intelectocan (intelectual + mitocan [intellectual + bumpkin]), (a) shoppingoni (shopping + (a) goni [to flap away]; to describe shopping fever, in AC, no. 1, 6.01.-12.01.2004, p. 5), publireportaj (publicitate + reportaj [publicity + reportage], in AC, nr. 5, 3.02.-9.02.2004, p. 5; the author ironically explains the meaning: "The publistory is a journalistic genre which, in exchange for a certain amount of money, does whatever the customer wants"); singur ciuciulete [drenched alone] (portmanteauexpression from Nina Cassian's poem Expresii improprii [Improper expressions]: singur cuc $+u d$ ciuciulete $^{20}$ ) [all by himself / all alone like a country dunny + drenched / soaked (to the skin)], etc.;

d) evocative lexical creations: Platon și Aristotel baronizîndu-se nițel / separatiști de tip Bruxelles [Plato and Aristotle playing a little the baron / Brussel separatists type] (pseudonym used in AC, second edition, which always rhymed with Aristotle and varied according to what was being described in the signed articles), Grigore după Ureche [(Grigore according to Ureche ${ }^{\mathrm{h}}$ ] (pseudonym used in AC), Ethos, Porthos și Aramis [Ethos, Porthos and Aramis] (the authors of the column entitled Mici fragmente de neant [Small fragments of nothingness], in AC), Bursucul gastric [The gastric badger] (the author of the column entitled Localul bălan [The white local ${ }^{i}$, in AC), Cronică a lu' Ștefan a Petrei [Ștefan a Petrei's Chronic ${ }^{j}$ ] (the author of the column entitled Săptămîna românilor [The week of the Romanians], in $\mathrm{AC})$, etc.

\section{Lexical creation and communicational complicity}

From a sociolinguistic perspective both imitation and lexical creation can be considered, as stated in Holmes (1997, p. 7), vocabulary choices which are triggered by various factors:

Not all factors are relevant in any particular context but they can be grouped in ways which are helpful. In any situation linguistic choices will generally reflect the influence of one or more of the following components

\footnotetext{
${ }^{18}$ Satirical publication founded in 1991.

${ }^{19}$ Recently, also căpuşarea (economiei) [ticking (of economy)].

${ }^{20}$ See the extended analysis of valise-expressions in Ene (2012a).

${ }^{\mathrm{h}}$ Grigore Ureche (1590-1647) was a Romanian chronicler (ureche, as noun in Romanian is ear).

iPlay on words from La Calul bălan (At the white horse - the name of a restaurant in Bucharest).

iȘtefan a Petrei is a character from the stories of Ion Creangă (Romanian writer, 1837-1889).
} 
1. The participants: $w h o$ is speaking and

who are they speaking to?

2. The setting or social context of the interaction: where are they speaking?

3. The topic: what is being talked about?

4. The function: why are they speaking?

(Holmes, 1997, p. 12).

It is expected that, according to all these factors, there should be a certain solidarity or, on the contrary, a certain distance in communication. In another article (Ene, 2012b), this solidarity was termed communicational complicity with reference to slang. The aim of the article was to illustrate the shift of emphasis from codification to expressiveness in slang, without eliminating the sense of belonging to a group/community, on the one hand, and keeping the cryptic function (if there is ever the need for the members of the group not to be understood by outsiders) once more by means of expressiveness, on the other hand.

In the same paper (Ene, 2012b), I have pointed out that some argotic elements enter/could enter the colloquial language precisely due to the attraction exercised by the degree of phantasy and humour that they involve. I then wondered whether expressiveness-which plays an important part in the decipherability of the slang, viewed as a secret language, towards more permissive types of slang or even towards other types of language (non-specialized, colloquial, etc.) - also has a role of concealment, thus turning into a slang in the strong sense of the term. I believe that the analysis conducted on three microseries - on inchisoare (prison), amantă (mistress) and informator (informer)-has helped me formulate the hypothesis that it can identify an intrinsic argotic communicational complicity (IACC) and an extrinsic argotic communicational complicity (EACC).

The argotic communicational complicity is inversely proportional to the expressiveness brought about by the re-semantization of the terms in the colloquial language: IACC entails a type of expressiveness (chiefly by means of metaphor) which targets the semic nucleus of the essential semes whereas EACC presupposes an expressiveness (especially by means of tropes belonging the metonymic class) which targets the semic periphery of the efferent or contextual distinctive semantic features.

According to our typological endeavour, the concept of communicational complicity cannot be extended to imitation but can be related to certain types of lexical creation-namely with 'luxury' lexical creations (pertaining to first category) and, respectively, with the portmanteau word lexical creations and with the evocative lexical creations (pertaining to second category). All these types of lexical creation entail a sort of expressiveness which could not be achieved in any circumstances, for any receptor, as they have a more or less elitist character. That means they involve a certain of initiation.

\section{Conclusions}

Lexical imitation and lexical creation are cases of linguistic creativity very well represented in Romanianthey ensure the development of the individual and of the collective lexis.

Lexical imitation mainly characterizes the accumulation stages of a language and lexical creation can be associated with every individual's stages of processing via culture, fantasy and imagination.

Lexical creation, through its forms that become ingrained in language or through the circulation power that they acquire as special creative elements in literature, ensures-along with other factors-the identity of the Romanian language and it is the expression of its speakers' inventiveness. This affirmation is based on a fact: the phenomena here depicted often involve-in their inspired forms-the metaphor, an expression of a very fast movement of the mind, as Tudor Vianu once described the essence of this mechanism (Vianu, 1968, p. 312).

The expressiveness present in some types of lexical creation presupposes a communicational complicity in the absence of which they would be unconceivable. It is up to time and our cultural development to reduce the elitist (nonetheless outstanding) character of some of them for the enjoyment of as many minds as possible. 


\section{Bibliography}

Avram, M. (1987). Probleme ale exprimării corecte [Problems of correct expressing], EARSR, Bucharest.

Avram, M. (1997). Anglicismele în limba română actuală [Anglicisms in current Romanian], Romanian Academy Publishing House, Bucharest.

Bidu-Vrănceanu, A. (1997). Dinamica sensurilor în româna actuală [The dynamics of meanings in current Romanian], in LL, 3-4, p. 39-44.

Capidan, Th. (1943). Limbă și cultură [Language and culture], Royal Foundation for Literature and Art, Bucharest.

Coteanu, I., Forăscu, N. \& Bidu-Vrînceanu, A. (1985). Limba română contemporană. Vocabularul [Contemporary Romanian Language. The Vocabulary], EDP, Bucharest.

Coșeriu, E. (1997). Sincronie, diacronie și istorie [Synchrony, diachrony and history], Encyclopædic Publishing House, Bucharest.

Dimitrescu, F. (1994). Dinamica lexicului românesc - ieri şi azi [The dynamics of the Romanian vocabulary - yesterday and today], Logos Publishing House, Bucharest.

Dimitrescu, F. (1997). Dicționar de cuvinte recente [Dictionary of recent words], Logos Publishing House, Bucharest.

Ene, A. (2012a). Peritextual Dialogue in The Dynamics of Poetry Translatability, in Ubaldina-Lorda, C. \& Zabalbescoa, P. (eds), Spaces of Polyphony, John Benjamins Publishing Company, Amsterdam, Crossref.

Ene, A. (2012b). Aspecte ale resemantizării în argou, in Buja, E. \& Măda, S. (eds), Structure, Use, and Meaning. Linguistic studies, Casa Cărții de Știință, Cluj-Napoca.

Gruiță, G. (2006). Moda lingvistică 2007 [The 2007 linguistic fashion], Paralela 45 Publishing House, Pitești.

Guțu-Romalo, V. (2000). Corectitudine și greșeală [Correctness and mistake], Humanitas Educațional, Bucharest.

Guțu-Romalo, V. (2005). Aspecte ale evoluției limbii române [Aspects of the Romanian language evolution], Humanitas Educațional, București.

Holmes, J. (1997). An Introduction to Sociolinguistics, Longman, London \& New York.

Hristea, Th. (1984). Sinteze de limba română [Syntheses of Romanian language], $3^{\text {rd }}$ edition, revised with new additions, Albatros Publishing House, Bucharest.

Lombard, A. (1969). Le vocabulaire d'emprunt. Questions de principe, in "Actes du X Congrès International des Linguistes", Bucharest.

Riemer, N. (2010). Introducing Semantics, Cambridge University Press, Cambridge, Crossref.

Stanciu-Istrate, M. (2006). Calcul lingvistic în limba română. (Cu specială referire la scrieri beletristice din secolul al XIX-lea), Editura Academiei, Bucharest.

Stoichițoiu-Ichim, A. (2007). Vocabularul limbii române actuale. Dinamică, influențe, creativitate [Current Romanian vocabulary. Dynamics, influences, creativity], BIC ALL Publishing House, Bucharest.

Vianu, T. (1968). Problemele metaforei [The problems of metaphor], in Studii de stilistică [Stylistics studies], EDP, Bucharest.

Volceanov, G. (2007). Dicționar de argou al limbii române [Slang dictionary of Romanian], Niculescu Publishing House, Bucharest.

Zafiu, R. (2001). Diversitate stilistică în româna actuală [Stylistic diversity in the current Romanian], Bucharest University Publishing House, Bucharest.

Zafiu, R. (2010). 101 cuvinte argotice [101 argotic words], Humanitas Publishing House, Bucharest. 